\title{
Walter L. Pohl: Economic Geology, Principles and Practice: Metals, Minerals, Coal and Hydrocarbons - Introduction to Formation and Sustainable Exploitation of Mineral Deposits (2nd revised edition)
}

\author{
Schweizerbart Science Publishers, Stuttgart, 2020, hard-cover (ISBN 978-3-510-65441-3; price $€$ \\ 94.00), soft cover (ISBN 978-3-510-65435-2; price $€$ 79.00) and ebook (ISBN 978-3-510-65436-9)
}

Frank Melcher ${ }^{1}$ (D)

Received: 10 May 2021 / Accepted: 17 May 2021 / Published online: 1 June 2021

(C) The Author(s) 2021

An updated edition of the Economic Geology, Principles and Practice by Walter L. Pohl is now available. Economic Geology, Principles and Practice is the follow-on to Petrascheck's "Lagerstättenlehre," which is a classic and will be familiar to many geologists. The father and son duo Wilhelm (1876-1967) and Walther E. Petrascheck (19061991) both worked at the Montanuniversität Leoben as department heads and as rectors, and co-wrote the original textbook "Lagerstättenlehre." First published in 1950, many generations of students have gained their knowledge of economic geology from this textbook.

Walter L. Pohl, emeritus professor at the Technical University Braunschweig and assistant to Walther E. Petrascheck in Leoben in the 1970s, has taken on the task of continuing this textbook (now in its 5th German edition, last revised 2005), and updating it for the modern geologist including an English-language edition (first published in 2011). Now in its second edition as a 755-page textbook, Economic Geology, Principles and Practice is more than a textbook; it is a globally unique compendium of modern knowledge on all topics of mineral resources and energy raw materials. Pohl's Economic Geology, Principles and Practice is therefore a worthy successor to the Petrascheck/Pohl's "Lagerstättenlehre."

Editorial handling: L. Nasdala

Frank Melcher

frank.melcher@unileoben.ac.at

1 Lehrstuhl für Geologie und Lagerstättenlehre, Montanuniversität Leoben, Peter-Tunner-Straße 5, 8700 Leoben, Austria
Economic geology is the application of geoscience to the supply of metals, minerals, and energy to society. The subject plays a central role in the exploration, evaluation, and development of deposits as well as in the mining and processing of raw materials. Economic geology is an indispensable discipline that is needed to meet mankind's increasing demand for nonrenewable raw materials and to further develop our society. In this expanded edition, Pohl is able to include current topics and crosslink them with future problems in the raw material supply. Thus, aspects of sustainable "green" mining, conservation of nature and the environment, and consequences for climate change are addressed within an ethical framework.

Economic Geology, Principles and Practice is divided into four comprehensive Parts. In the first, the deposits of the metals are dealt with over 300 pages. In keeping with previous editions, the processes leading to the accumulation of metals in the Earth's crust and mantle ("metallogenesis") are treated first, and are described in detail and with the most up-to-date sources. Important subchapters are dedicated to the investigation methods for hydrothermal deposits as well as an outline of metallogenesis in the course of the Earth's history. This is followed by a chapter which is subdivided by the individual metallic raw materials, which are organized under the subheadings: iron and steel metals, nonferrous metals, precious metals, light metals as well as minor metals and specialty metals (including uranium and thorium), including many of the so-called critical raw materials. These individual chapters contain a veritable flood of interdisciplinary information and are a treasure trove for students, professors, professional geologists, and mineral enthusiasts. All relevant areas are represented including: mineralogy and geochemistry, deposit types and classification (numerous current examples), economic aspects, and notes on mining and processing. 
Part 2 deals with non-metallic raw materials in 130 pages. Industrial minerals are defined as those raw materials that are not used for the extraction of metals or energy, but for their mineral properties, such as hardness, color, or heat resistance. In addition, there are the bulk raw materials for the construction industry, known as "earths and rocks". Analogous to the metal ores, 28 subchapters provide important facts on mineralogy, geochemistry, uses, and deposits of these groups of raw materials. Here, too, current research results and descriptions of deposits are included, with an emphasis on European deposits.

A separate chapter herein is devoted to salt deposits. In addition to a presentation of the scientific investigation methods, the geological processes of salt formation today and in the past are explained in detail. A separate paragraph is devoted to the Alpine Haselgebirge, in which modern interpretations are also given space. Highly relevant to the issues of radioactive waste disposal is the subchapter on salt deformation and halokinesis. It concludes with a separate chapter on exploration and mining of salt deposits.

Part 3 covers the practical side of economic geology in just under 50 pages. This includes the geological concepts and methods that play a role in mining including: exploration, extraction of raw materials, and mine closure. Examples of successful exploration concepts are presented and both classical and modern methods of exploration are explained. These topics are particularly important for mining engineers, as this is where most of the technical points of intersection with the geosciences lie. Thus, the principles of deposit evaluation are presented, as well as the rather new field of geometallurgy. Also topical and important, are the remarks on the subject of mining and the environment. Here the potential environmental risks, environmental management, and the post-mining phase are dealt with. The chapter concludes with remarks on the topic of final disposal of hazardous wastes in geological structures.

Properties, formation, evaluation, and environmental aspects of solid, liquid, and gaseous fossil biomass energy feedstocks are presented in nearly 110 pages in Part 4 . In the chapter on coal, Walter Pohl also addresses the issue of $\mathrm{CO}_{2}$ emissions and geological sequestration (CCS), as well as the influence of $\mathrm{CO}_{2}$ on the paleo- and present-day climate - keyword greenhouse effect. $\mathrm{He}$ also emphasizes the enormous need for research in the field of paleoclimate and in the influence of greenhouse gases on climate. Coal is an important energy source that will still be available in large quantities in the future. Although the importance of coal is dwindling, especially in Europe, it is important for future generations to preserve the techniques for characterizing coal types and their exploration and extraction. This is perfectly achieved in the corresponding subchapter, since all the essential information on the formation of coal deposits, but also on mining and the management of post-mining landscapes, is collected. The last subchapter is devoted to the fossil hydrocarbons petroleum and natural gas. In just under 60 pages, the various hydrocarbons are presented here in a now familiar way and, in a condensed form, their formation processes are explained and exploration/ production are addressed. Unconventional hydrocarbons such as oil shale, as well as a critical outline of the environmental aspects of oil and gas production conclude the chapter. Here the reader learns some interesting details about accidents in this industry.

The relevance of Economic Geology, Principles and Practice is reflected not only in the incorporation of the latest literature, but also in the fact that cutting-edge geological concepts have been incorporated which significantly change the understanding of reservoir formation. Although the book is aimed at a global audience, it should be emphasized that in addition to the most globally significant, many smaller European deposits and deposit provinces are also covered. This will enable readers of this book to better understand deposits and reservoirs they might know from their own travels.

Walter Pohl's Economic Geology, Principles and Practice is very well illustrated with 305 black-and-white illustrations, as well as 32 large-format color plates at the end of the text. In addition, there are 22 tables and 25 boxes of interesting supplementary information that significantly break up the often highly condensed text. The bibliography comprises 78 pages and has been supplemented by up-to date publications. Finally, in addition to the general index, there is also a localities index, which helps in the targeted search for deposits.

The work is of an astonishing breadth and comprehensiveness. Basic knowledge of geology and mineralogy as well as some technical knowledge will make it easier for beginners to get started with this book. But with prior knowledge, it will captivate anyone interested in raw materials. This is a wonderful reference textbook that you will find yourself rereading again and again, whether to study a chapter in more detail, to look something up, or simply to learn something new. I highly recommend it to all mining geologists, reservoir geologists, and applied geoscientists.

Funding Open access funding provided by Montanuniversität Leoben.

Open Access This article is licensed under a Creative Commons Attribution 4.0 International License, which permits use, sharing, adaptation, distribution and reproduction in any medium or format, as long as you give appropriate credit to the original author(s) and the source, provide a link to the Creative Commons licence, and indicate if changes were made. The images or other third party material in this article are included in the article's Creative Commons licence, unless indicated otherwise in a credit line to the material. If material is not included in the article's Creative Commons licence and your intended use is not permitted by statutory regulation or exceeds the permitted use, you will need to obtain permission directly from the copyright holder. To view a copy of this licence, visit http://creativecommons.org/licenses/by/4.0/.

Publisher's note Springer Nature remains neutral with regard to jurisdictional claims in published maps and institutional affiliations. 